\section{Lettlest på norsk om utviklingspsykologi}

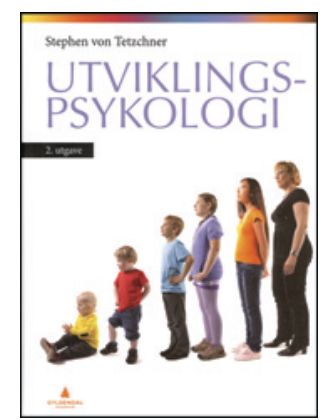

Stephen von Tetzchner

Utviklingspsykologi

2. utg. 880 s, tab, ill. Oslo: Gyldendal

Akademisk, 2012. Pris NOK 735

ISBN 978-82-05-39078-2

Dette er en norsk bok om utviklingspsykologi i ny og oppdatert utgave. Den er rettet mot alle som i sin utdanning og virke trenger kunnskap om barn og unge i utvikling.

Forfatteren presenterer den utviklingspsykologiske tenkemåten som er sentral både for å få innsikt i det felles menneskelige og forstå forhold som gjør barn unike. Han hevder at både teoretisk og empirisk kunnskap er nødvendig i klinisk arbeid og forskning. Leseren gjøres kjent med teorier innen feltet og føres inn en kontinuerlig diskusjon om teorier holder mål i møtet med ny viten. Forfatteren presenterer teoridreven psykologisk forskning på en flott måte. Vinklingen er spennende for en medisiner som ofte har innfallsvinkler via klinisk arbeid.

Selv om dette ikke er en bok om avvik, gir teksten hyppig innblikk i punkter der ting kan «gå feil». Forfatteren har selv bakgrunn fra arbeid og forskning med barn med ulike funksjonshemninger, noe som er en styrke.

Boken er oppdelt i hovedkapitler med underkapitler. Noen kapitler er omarbeidet og utvidet, kapitlet Sinn og forståelse er nå et eget kapittel, og det har kommet til noen nye kapitler. Tematisk dekker boken utviklingspsykologien med vekt på hjernens utvikling, kognitive prosesser, den perseptuelle utviklingen og motorisk utvikling. I kapitlene om emosjoner har forfatteren lagt vekt på reguleringen av emosjoner og hvordan forstyrrelser av denne bidrar til psykiske symptomer.

Generelt er søkelyset rettet mot de aller første leveårene. Utviklingen hos et barn skjer i samspill med omgivelsene, ikke minst de første omsorgspersonene. Dannelsen av sosiale relasjoner i barndom og ungdom er viet stor plass. Både morsomt og interessant er det nye kapitlet om livsløpsperspektivet med særlig vekt på aldring. Underveis henviser forfatteren hele tiden til likheter og forskjeller mellom kjønnene og mellom kulturer.

Kapitlet om gener, evolusjon, arv og miljø er noe utvidet, men det biologiske miljøet omtales lite, og epigenetikken er sparsomt behandlet. Den aller nyeste forskningen som bruker bildediagnostikk for å belyse det sentrale nervesystemet og utviklingsforhold, f.eks. hos premature barn eller hos barn med ulike psykiske vansker, kunne med hell vært trukket inn, men ligger muligens utenfor forfatterens område.

Teksten er lettlest og har god flyt. Leseren nyter godt av at det kun er én forfatter, noe som hindrer overlapping og gjentakelser. Forfatteren har lagt vekt på å finne norske ord og uttrykk. Illustrasjonene er flere og ofte i farger. Nytt er tabell med sentrale begreper, studiespørsmål og henvisning til Internett-ressurser på slutten av hvert kapittel. Inne i teksten er det mange henvisninger, også til andre steder i teksten, som viser hvor god oversikt forfatteren har.

Jeg anbefaler boken både til den som er interessert i å forstå mennesker bedre, og som oppslagsbok i praktisk arbeid med barn og unge.

\section{Lærebok og oppslagsverk om verdibasert ledelse}

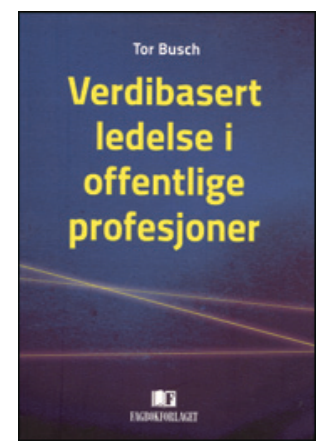

\author{
Tor Busch \\ Verdibasert ledelse i offentlige profesjoner \\ 185 s, ill. Bergen, Fagbokforlaget, 2012. \\ Pris NOK 349 \\ ISBN 978-82-450-1351-1
}

Tor Busch har igjen kommet med en viktig bok angående ledelse i offentlig sektor. Målgruppen er alle som ønsker en dypere forståelse av den komplekse dynamikken i organisasjon og ledelse som særpreger kunnskapsbedrifter med sterke profesjoner. Forfatterens intensjon er å legge grunnlag for, og rette søkelyset mot, verdibasert ledelse i offentlig sektor. Det er en systematisk gjennomgang av grunnleggende teori på området.

Forfatteren går spesielt i dybden på hva som særpreger profesjoner i forhold til verdier og etikk. Samtidig setter han dette inn $i$ et helhetsperspektiv og danner grunnlag for drøfting av profesjonsetiske problemstillinger. Han skisserer også en modell for verdibasert ledelse som tar utgangspunkt i etablerte verdier og utviklingen av disse. Selvledelse, teamledelse og transformasjonsledelse tas særskilt opp. Forfatteren berører prosessen fra å være nybegynner til å bli ekspert og hvilke implikasjoner dette har for ledelsesform og verditenkning.

Offentlig sektor er i rask endring. Profesjonene står fortsatt sterkt, men blir utfordret på mange områder. Stadig økende krav til effektivitet og resultatstyring med kontroll skaper dels frustrasjoner og kan ha implikasjoner med demotivering og konflikter. Årsaken mener Tor Busch blant annet ligger i at forskjellige aktører i offentlig sektor har forskjellig verdigrunnlag som de måler suksess ut fra. Inntoget av «New public management» har, ifølge forfatteren, ikke lagt nok vekt på nettopp verdigrunnlag og kultur som finnes innen profesjoner og i offentlige institusjoner. Med denne boken dokumenterer han noen av de utfordringene dette medfører. Eksempler er at man måler det som kan måles, og bruker mye tid på dokumentasjon av fakta som ofte ikke gjenspeiler fagfolkenes syn på hva som er viktig å måle. Betydningen av muligheten for godt skjønn og at ikke alt kan måles blir understreket. Busch knytter også sammen teorier om verdigrunnlag og behov hos medarbeiderne. Dette er viktige elementer for å forstå hvordan man skal lede og motivere kunnskapsarbeidere.

Et viktig poeng er å bli bevisst på hvilke verdier som trekkes inn i en ledelsesprosess, om hvilke som er relevante, og hvilke som bygger på hverandre eller er i konflikt. Om nødvendig må verdiene rangeres etter viktighet og prioriteres. Dette er nok en prosess som ikke alle ledere har vært seg særlig bevisst.

Boken er bygd opp som en lærebok med henvisninger til relevant litteratur, og den har oversiktlige figurer og modelltegninger. Den har en enkel innbinding med en oversiktlig layout, er lettlest og kan brukes som både lærebok og oppslagsverk. Til tross for at forfatteren legger vekt på de teoretiske aspektene har boken svært relevante dagligdagse implikasjoner. Min oppfatning er at innholdet i boken gir grunnlag for en rekke aha- opplevelser. Jeg anbefaler boken spesielt til alle som har interesse for ledelse og organisering, både i offentlig og privat sektor på alle nivåer. 